Mursalov M. M., Ph.D. (Economics), Senior Lecturer Azerbaijan State University of Economics (UNEC) Baku, Azerbaijan

DOI: https://doi.org/10.30525/978-9934-26-018-6-28

\title{
REGULATION OF THE BANKING SYSTEM - IMPORTANT COMPONENT OF THE COUNTRY'S ECONOMIC SECURITY MECHANISM
}

Regulation of the activities of banks as the most active participants in the global financial market is a set of measures in the field of financial and economic relations aimed at streamlining the functioning of market institutions, both at the national, and at the regional and international levels. The significant place of regulation of the banking system is determined by the goals that can be achieved with its help: 
- support of the financial stability of the bank and the stability of its functioning;

- formation of a system of standards and requirements necessary for this;

- providing conditions for the balance and stability of banking in the financial market.

The implementation of these goals will largely contribute to the achievement of banking security, which is of great importance for the country's economic security. For this, the country's banking system, the highest level of which is the Central Bank, must have the necessary potential to not only contribute to the achievement of the goals and objectives of the country's macroeconomic development, but also, ideally, create impulses for it and resist internal and external threats.

Security, as a socio-economic phenomenon, in today's realities is one of the global factors in the development of civilization. Without taking it into account, no solution can be implemented to ensure the functioning of economic systems, including banking. The need to ensure the security of the banking system is due to the fact that the modern world financial market has undergone significant changes in its development, has reached such a level when its subsequent improvement is carried out in the framework of increasing uncertainty. Under such conditions, any actions aimed at obtaining promising results are inevitably characterized by a high level of risk. Currently, there is a growing tendency to intensify destabilizing moments and, first of all, from the point of view of creating under their influence all sorts of dangers and threats to the banking system. All this requires the application of appropriate protection and countermeasures, including in the field of banking regulation [2].

Analyzing the practice of regulating the banking system in the context of ensuring its security, the following are among the priority tasks [3, p. 351-370]:

- protection of the legitimate interests of banking institutions in the course of their activities in the banking services market; 
- timely identification of real and potential threats to the banking system, causes and conditions that may contribute to their emergence, implementation of measures to neutralize the dangers and threats and counter them;

- prompt response to emerging threats and negative trends in the development of the external and internal situation;

- identifying the reasons and creating conditions conducive to the implementation of the main interests of the banking system;

- preservation and effective use of financial, material and information resources of banking institutions;

- ensuring the activities of banks in extreme conditions.

The security of the banking system of the country's leading role belongs to the Central Bank of Azerbaijan (CBA). During the crisis period, the $\mathrm{CBA}$ took measures aimed at reducing banking risks associated with lending operations. In particular, a ban was introduced on lending in foreign currency to those borrowers who did not have sources of foreign exchange earnings. Also, recommendations were developed on the restructuring of loans, the procedures for writing off and selling loans were simplified, and stricter requirements were introduced for the formation of reserves to cover possible losses on credit operations of banks. To further improve the mechanism for regulating credit activities, it is necessary, first of all, to develop a set of measures for countercyclical banking supervision. The aim of this regulatory approach is to amortize credit shocks and smooth out the influence of negative factors throughout credit cycles. Implementation mechanisms imply the creation of financial buffers and additional reserves during credit booms, which will be used during a period of increasing threats to the security of the banking system.

The timeliness and completeness of the banking system's performance of its functions largely depends on the liquidity of banks, which is one of the qualitative characteristics of its activities that determine the provision of banking security. An important component of the liquidity management of the banking system is its regulation by the mechanisms and instruments of the monetary policy of the Central Bank. In Azerbaijan, such management is legislatively based mainly 
on effective tools, developed by world practice. In particular, according to the current legislation, the Central Bank of Azerbaijan has such banking regulation instruments as economic standards, mandatory reserves, interest rate policy. Insufficient liquidity leads to the insolvency of credit institutions. The level of liquidity risk is affected by various factors, among which standout such as the quality of banks' assets and their diversification; the interest rate policy of banks and the general level of profitability of their operations; the amount of currency and interest rate risks; stability of bank liabilities; consistency in terms of attracting resources and placing them in active operations, the image of banks.

One of the most important characteristics that are the subject of banking regulation and affect the security of the banking system is the level of its capitalization. It is the sufficient level of equity capital that ensures economic independence, profitable functioning in the banking services market, which ultimately has a positive impact on the financial stability of the banking system. Structural imbalances can be avoided and the quality, harmony and transparency of capital can be improved through a number of banking regulation measures:

- implementation of fiscal measures to stimulate the direction of profit to increase the capital of banks and capitalization of dividends;

- changes in approaches to increasing reserve capital, taking into account the unstable economy, transition to countercyclical regulation;

- strengthening supervision and adoption of new rules for accounting in capital of the results of revaluation of fixed assets and securities, the volume of reserves for active operations;

- increasing the transparency of the ownership structure.

As noted in the "Statement of the Central Bank of the Republic of Azerbaijan on main directions of the monetary and financial stability policy for 2020 and medium term" [4, p. 13], the Central Bank will increase efforts to make the financial sector more resilient to risks and deepen financial intermediation, money and capital markets. It is envisaged to take effective measures to complete financial sector restructuring and regulate problem assets. All this should increase the 
role of the banking sector in enhancing the country's economic security.

Prevention of risks accumulation in systemically important financial institutions during the banking system rehabilitation will be a top priority. The Bank will attach a particular importance to problem assets as part of maintaining the quality of banking sector assets. Accordingly, the Bank will promote use of advanced risk management principles in more effective decrease in the size of problem loans and issue of new loans by credit institutions. 14 The Bank will focus on maintaining an acceptable level of and creating effective mechanisms to manage liquidity. Central Bank's liquidity tools will be critical in safeguarding banking system liquidity. Moreover, greater volume of state securities and development of the interbank credit market will also positively factor in flexible regulation of the liquidity position by banks. The Central Bank will more tensely monitor the financial sector and focus on revealing possible systemic risks and potential crisis probabilities in financial markets, and take related policy measures. The Central Bank will preventively provide stress test based simulation of the status of financial sector against various economic shocks and make relevant interventions to the sector if necessary. In the year to come the Central Bank will take efforts to improve the banking supervision framework and apply risk-based and countercyclic prudential regulation. The Bank is planning to launch preliminary pilot works to introduce riskbased supervision based upon a new methodological approach.

\section{References:}

1. Regulation of Banking in Ukraine and Russia in the Context of Globalization: Monograph. Ed .: M.I. Dyba, E.A. Zvonova. Kiev: KNEU, 2013, 380 p. (in Russian)

2. National Security Concept of the Republic of Azerbaijan. Approved by the Order of the President of the Republic of Azerbaijan dated May 23, 2007 No. 2198.

3. The Political Economy of Bank Regulation in Developing Countries. Ed.: E. Jones. New York: Oxford University Press, 2020, xxvii, 386 p. DOI:10.1093/oso/ 9780198841999.003.0001.

4. Statement of the Central Bank of the Republic of Azerbaijan on main directions of the monetary and financial stability policy for 2020 and medium term. Baku: CBA, 2020, 18 p. 